\title{
Smallpox and polio eradication in India: comparative histories and lessons for contemporary policy
}

\author{
Erradicação da varíola e da pólio na Índia: \\ histórias comparativas e lições para políticas contemporâneas
}

Sanjoy Bhattacharya ${ }^{1}$ Rajib Dasgupta ${ }^{2}$
${ }^{1}$ Department of History, University of York. Heslington, York, YO10 5 DD, United Kingdom. sanjoy.bhattacharya@york.ac.uk ${ }^{2}$ Centre of Social Medicine and Community Health, Jawaharlal Nehru University, India.

\begin{abstract}
This article argues that a detailed examination of factors contributing to the development of complex structures and strategies for smallpox eradication in South Asia in the 1970s can provide fruitful indications for the reformulation of the national chapters of the global polio eradication programme in this region. There is a magnificent archive in the WHO's Geneva offices, which details how smallpox eradication outbreaks were located and then contained in cities, small towns and remote rural areas in this region, by teams of international workers working closely with local officials. A systematic assessment of the global smallpox eradication efforts indicates parallels between the early stages of the global smallpox eradication programme and the present situation of the polio campaign; as we will see here, it can also provide useful indicators for future action in South Asia and beyond.
\end{abstract}

Key words Global health history, Smallpox eradication, Polio eradication, Indian public health, Vaccines
Resumo O artigo argumenta que um exame detalhado dos fatores que contribuíram para o desenvolvimento de estruturas e estratégias complexas para a erradicação da varíola no Sul da Ásia nos anos 70 pode fornecer indicações proveitosas para a reformulação dos capitulos nacionais do programa global de erradicação da pólio nesta região. Existe um impressionante arquivo nos escritórios da OMS em Genebra que detalha como os ataques para a erradicação da varíola foram localizados e então contidos em cidades, pequenas vilas e áreas rurais remotas desta região, por equipes de profissionais internacionais trabalhando em conjunto com as autoridades locais. Uma avaliação sistemática dos esforços globais de erradicação da varíola indicam paralelos entre os estágios iniciais do programa global de erradicação da varíola e a atual situação da campanha contra a pólio. Como veremos aqui, o artigo também pode fornecer indicadores úteis para ações futuras no Sul da Ásia e em outros locais.

Palavras-chave História da saúde global, Erradicação da varíola, Erradicação da Poliomielite, Saúde pública indiana, Vacinas 


\section{Introduction}

Reports have quite recently noted the outbreak of polio within Western Africa and Southern Asia. Declarations by the World Health Organization headquarters in Geneva, Switzerland (WHO) and its South East Asia Regional Office in New Delhi, India (WHO SEARO), about the future prospects of eradicating polio across the globe, therefore, reveal more than a hint of anxiety. Yet, as options and new strategies are weighed up by members of the different United Nations organizations, national aid agencies and global funding bodies, one important set of lessons appear to have been consistently ignored: those presented by the successful eradication of smallpox, which was formally ratified by the World Health Assembly in 1980. As in the 1970s, the South Asian sub-continent - and, in particular, locations within Northern and Eastern India - is providing major hurdles for the successful completion of a major global disease eradication programme.

The argument that smallpox and polio are distinct diseases and, therefore, lessons cannot be carried over from one eradication programme to the other is both disingenuous and sterile. While it is true that symptoms of infective polio and smallpox cannot be more different - and, therefore, require distinct means of identification and reporting - we need to remember that diseases and the plans to eradicate them cannot be treated as entities purely defined by medical science. Significant elements of both are deeply influenced by a range of social and political conditions, as people in different walks in life often perceive causes of - and possible cures for - illness in widely varied ways. Public health officials are, therefore, forced to navigate complex administrative and societal terrains, where knowledge gleaned from scientific and medical journals - and the passage of inflexible strictures passed by a handful of officials from distant centres of authority - can only be partially useful; points worth remembering even though global funding agencies involved in blinkered quests for magic bullets continue to downplay or ignore these points. The results of careful negotiations carried out with local public health workers, political and community leaders, and members of the general populations, which provide information crucial to operational success, are of far greater use. From this perspective, one can argue that immunisation campaigns of all types are deeply social and political phenomena; a message public strategists and funders can only ignore at their peril.

\section{The global smallpox programme and India}

The World Health Assembly (hereafter WHA) started considering the prospect of eradicating smallpox worldwide started as early in 1950 - discussions on the topic were held within the WHA that year, as well as 1953, 1954 and 1958. Indeed, Dr. Brock Chisholm, the WHO's first Director General, proposed global smallpox eradication in 1953, even if these discussions did not progress particularly far. Noticeable progress on the issue was witnessed at the $11^{\text {th }}$ WHA, which was held at Minneapolis, USA, in 1958, where Professor Viktor Zdhanov, the USSR Deputy Minister of Health, argued that the eradication of the variola virus was both theoretically possible and important to the world as a whole, including countries that had managed to expunge the disease within their territories. His views - and the proposal put forward by him in the shape of what is often referred to as the so-called "Zdhanov resolution" - received broad-based support at the gathering, leading the WHO's Executive Board to meet immediately after the WHA and announce preparations for a future smallpox eradication drive. In Geneva, this took the shape of the acceptance of donations of freeze dried smallpox vaccine from the USSR and glycerolated vaccine from Cuba, which was used to create an "account" that would distribute stocks to countries where eradication campaigns were initiated; the decision also resulted in discussions with officials based in the WHO regional offices and national governments in charge of smallpox endemic territories ${ }^{1}$.

Officials based in India, a major reservoir of smallpox cases, were brought into discussions soon after the passage of the 1958 resolution. These negotiations, which involved senior members of the WHO, WHO SEARO and Indian federal government, did not go smoothly in a situation where there was disagreement even about the most basic issues, like the exact definition of smallpox eradication. It also did not help matters that WHO officials based in Geneva attempted to impose a fixed set of ideas and policies on people based in New Delhi, including people serving in WHO SEARO. Interestingly, the problems continued even after the WHO officials based at different locations agreed upon specific policies the fact that these strategies were offered to the Indian authorities as an inflexible blueprint, without any substantive offer of financial support for making their implementation possible, did not go down well in the corridors of power. Indeed, this situation ensured that calls for small- 
pox eradication emanating from Geneva in the late 1950s and early 1960s received a rather frosty reception across the Indian political spectrum ${ }^{2}$.

The tide of Indian disinterest began to slowly turn only in the mid-1960s, after the WHO departments charged with starting planning work on smallpox eradication re-organised themselves. Interestingly, this involved employing people who were more willing than their predecessors to engage with Indian politicians and public health officials, in order to develop common ground before an organised push to eradicate variola was launched ${ }^{3}$. An increased budget, which allowed the relevant WHO departments to fund agreed plans and share some costs with the Indian health departments in Delhi and the states, helped matters along. The results were impressive at one significant level. The Indian federal authorities agreed to organise district-level pilot projects within each state, based, at least on paper, the commitment of comprehensive numbers of local health staff. This was considered helpful within the WHO, as it held out the promise of allowing for the collection of information that would reveal if the smallpox eradication plan was workable ${ }^{4}$.

At another level, though, insurmountable problems began to make an almost immediate appearance, despite the announcement of reforms by the Indian authorities at frequent intervals. The preliminary Indian national smallpox eradication programme, which was planned in association with WHO representatives, was, therefore, fragmented and weak even as late as 1965. Several factors ensured this. The "liquid" smallpox vaccine was unreliable and the freeze dried variety was short in supply; international donors like the Unicef appeared to have relatively little inkling of the infrastructural situation in the country and provided items like electric refrigerators for vaccine storage in areas that had intermittent or no electricity; several state and district level administrators remained hostile to the eradication goal, there were wide variations in the capabilities of vaccinating and supervisory staff across states and their districts, and lack of ideological unity within the WHO offices and Indian government departments resulted in operational confusion in the field. It did not help at this stage that the WHO was unable to commit field workers to the pilot projects; instead, organizational field representatives appeared to quickly move in and out of districts, without developing any substantive links with local health workers. So, to the great frustration of several officials based in Geneva, most pilot projects started late, overshot agreed timetables and, often, came up with defective data ${ }^{5}$.

All these experiences quickly taught senior WHO representatives that it was far easier to draw up collaborative plans in the sub-continent than to arrange for their implementation. The experience also brought home, by the mid-1960s, the important fact, that they could not hope to micro-manage the programme, top-down, from a great distance. As a consequence of the problems faced in the vast majority of Indian states, splits began to appear within the WHO firmament - it was reported that senior WHO SEARO officials, including the Regional Director, were openly expressing doubts about the possibility of ever eradicating smallpox. This, in turn, emboldened critics of the proposed programme within Indian federal and state governments, including members of the office of the Indian Director General of Health Services, to criticise the plan to expunge variola. The problem deteriorated to such an extent by 1967, that people within the WHO's Smallpox Eradication Unit feared that the Indian government would cut back its support very substantially - and potentially even withdraw - from the programme ${ }^{6}$. The situation was finally rescued by a series of time-consuming and placatory diplomatic initiatives managed by the Unit's Chief, Donald A. Henderson, who travelled to India for negotiations with several senior government officials, including those based in the prime minister's office. These efforts bore fruit and a new deal was struck, where the Indian federal authorities agreed to continue to be supportive of global smallpox eradication - they agreed to streamline the health services department, create a more dynamic smallpox unit within it and also commit greater resources to state-level smallpox eradication efforts from 1968 onwards $^{7}$.

However, the WHO's success in these negotiations came at a price. The organisation was forced to commit greater levels of financial assistance and personnel to the sub-continental campaigns, and promise a re-organisation of activities within WHO SEARO ${ }^{8}$. All these developments, which began to have a measurable impact on field activities from 1970 onwards, were important in the long run; these readjustments set into place a structure that was to gradually produce an administrative environment conducive to the successful eradication of smallpox. Particularly significant was an arrangement where the WHO's Smallpox Eradication Units in Geneva and New Delhi began to work in close association with a similar body set by the Indian government; Nicole Grasset, a 
remarkable French official, was charged with coordinating the work from the Indian capital. Officials attached to all three bodies met on a regular basis, collected information from the states and their districts, developed policies together, and set up mixed teams of international and Indian workers; these teams were given the responsibility of going into the states, searching for smallpox cases, and putting containment and vaccination schemes into place. Henderson and Grasset expected these workers to spend significant amounts of their time in India in the field ${ }^{9}$.

Interestingly, most international and Indian workers were supportive of this arrangement, even though this adversely affected the health of many. Those unwilling or unable to put with the rigours of the posting were quietly moved on; to other government departments if they were Indian and out of the country if they drawn from abroad. The policy was quite ruthlessly enforced, so that the Indian smallpox eradication programme was, between 1971 and 1975, in the hands of a small core of well organised workers, who respected each others' abilities and were encouraged to adapt policies to the numerous social, political and economic conditions encountered in the field. In this regard, mobile teams were encouraged to draw upon the help of staff drawn from local communities and, crucially, given access to the financial means to offer generous short-term employment contracts. The information provided by this diverse group of workers, who were accorded the role of valued partners in the management local campaigns, proved crucial to the development of socially and politically acceptable - and, thus, effective - policies (most notably so in major states such as Rajasthan, Uttar Pradesh, Bihar, Madhya Pradesh and Bengal $)^{10}$.

These developments were significant contributors to the implementation of surveillance, containment and vaccination work, without a general recourse to brute force. J.R.D. Tata, the Chairman of Tata Industries proved to be an invaluable ally during the Bihar smallpox epidemic in 1974, both at a local and a federal level; his personal rapport with Indira Gandhi, India's powerful prime minister, proved invaluable to the WHO's smallpox eradication units in Geneva and New Delhi ${ }^{11}$. It is important to note that compulsion was usually deployed with the support of federally controlled police and military forces, usually after discussions with local parliamentary representatives had been carried out (strikingly, a phase extra-constitutional rule introduced by the "Emergency" of 1975-77 reduced the com- plexity of local negotiations, but did not cause their discontinuation $)^{12}$. Despite the existence of some variations in the effectiveness of the mobile teams of epidemiologists, health workers and local community workers, it is important to recognise that this strategy created for the first time an international workforce that was allowed to work relatively freely in the country, once government clearances for the officials had been received. Some regions, like politically sensitive frontier regions bordering China and Pakistan, remained off limits to workers of some nationalities and could only be accessed by teams of Indian workers ${ }^{13}$.

For a variety of reasons, making all these new arrangements was not an easy process, by any means. WHO SEARO retained a great degree of autonomy and its Director continued to harbour serious doubts about the smallpox eradication programme. Yet, over time, Henderson and his supporters within the $\mathrm{WHO}$ - an agency that was not united on the issue either, especially as significant elements of the Indian campaigns continued to struggle in the early 1970 s - were able to counter this opposition through a variety of measures. At one level, this team was able to negotiate the creation of a special fund, with significant Swedish assistance, which the WHO's smallpox eradication units were able to draw upon, without timeconsuming clearances from the WHO SEARO Director and the Indian government. At another, people like Henderson, Grasset and Larry Brilliant kept working hard to develop good working relations with parliamentary representatives, other politicians and their financial backers, based at all levels of government and society. Some of these connections proved invaluable at crucial junctures of the programme - the significant economic, material and political support provided by J.R.D. Tata during the epidemic outbreaks of 1974 in Bihar is perhaps the best example of such trends. And at yet another level, efforts were consistently maintained to keep all major foreign donors abreast of the true epidemiological situation and administrative problems in South Asia; this operational transparency was crucial to winning the trust of senior officials working within organisations like the Swedish International Development Agency, USAID and Soviet Academy of Medical Sciences, who, in turn, would come up with sorely needed assistance at crucial junctures ${ }^{12,14}$.

Seen from this perspective, the question of eradicating smallpox in India was never purely a medical or biological issue, and never presented simplistically as such by those responsible for its eradication. It was, by necessity, a far more intri- 
cate phenomenon, which required careful preparation and implementation. In this regard, tackling all manner of administrative, political, social and economic complexities was as important as getting the vaccine technologies and the operating methods right. Put another way, the widespread adoption of freeze-dried vaccine and the bifurcated needle was important. But so was the adoption of several other decisions - namely, the development of containment and immunisation policies that were sensitively adapted to local conditions and infrastructural conditions with the help of community partnership programmes, as well as the consistent efforts to ensure that these campaigns were managed by workers who were spending significant time in the field. Indeed, international workers often played the important role of accessing information from South Asian health workers of all ranks, which were then used to good effect; touring epidemiologists employed by the WHO were also frequently able to ensure that the views of junior and mid-level Indian and Bangladeshi health officials were not rejected outright by state- and federal-level representatives in the sub-continent. This point is often made by international workers who recognise that they were receiving ideas from national and local workers, which were then made the basis of important, region-specific policy adaptations ${ }^{15}$. The following section considers whether the adoption of such strategies might be useful to the contemporary Indian polio eradication programme.

\section{The Indian polio eradication programme: contours, problems and futures}

A 1983 meeting of public health experts in Bellagio considered, for the first time, the idea of polio eradication as a component of the Expanded Programme on Immunisation (EPI) ${ }^{16}$. The following year, Rotary International constituted a consultative committee to consider the potential of this goal; the result was a declaration that efforts would be made to eradicate polio by 2005 . This was followed by the 1985 Pan American Health Organisation (PAHO) resolution to eradicate polio from the Western hemisphere by 1990 166 member countries adopted, in 1988, the goal of global polio eradication by 2000 at the WHA. The initiative was projected as an "appropriate gift, together with the eradication of smallpox, from the twentieth to the twenty-first century" ${ }^{17}$. The Global Polio Eradication Initiative (GPEI) was, thus, born.
Yet, the unanimity characterising the WHA 1988 resolution about the meaning of - and the strategies required for - polio eradication turned out to be inconstant. At this assembly, eradication had been defined as the complete absence of the disease following concerted public health interventions; however, discussions and declarations from within and outside the confines of the WHO subsequently displayed a far less clear cut approach to the issue ${ }^{18}$. The Global Commission for the Certification of the Eradication of Poliomyelitis has, of course, defined the term "eradication" as the absence of circulation of all indigenous wild polioviruses for at least a three year period during which surveillance activities had been maintained ${ }^{19}$. Alternative assessments about the form and possibilities of polio eradication have persisted side by side since the launch of the GPEI; a variety of constituencies and viewpoints appear to have been responsible for these definitional and attitudinal complexities ${ }^{18}$. Some suggested that the disease could be eliminated through regularised immunisation programmes, based on careful surveillance and systematic OPV-based immunisation of infants; ideas that continue to be advocated tenaciously by those arguing for a changed approach towards the global fight against polio ${ }^{20}$.

In India, OPV-based work was included in the EPI in 1978-79, which was subsequently upgraded to a Universal Immunisation Programme (UIP) in 1985. The "Polio Plus" programme was initiated in Tamil Nadu state in 1986 with a grant of US\$2.6 million from Rotary International; this was followed by another US\$20 million grant from the same source, for financing the procurement of OPV, cold chain support, surveillance activities and social mobilisation across the country. A staged approach to eradicate polio followed in eleven other states, and the stated aim was to extend the programme to other parts of the country after that ${ }^{21}$. The expanded project took the shape of the so-called "Pulse Polio" initiative (PPI), which was initiated in the Tamil Nadu, Kerala and Delhi states during 1994. Also referred to as the "Supplementary Immunisation Activities", the strategy involved the mass immunisation of a target population of children up to five years of age, on pre-arranged immunisation days irrespective of their earlier vaccinal status. A country-wide pulse polio programme was put into place from July 1995, after the state governments responded to concerted federal calls for its extension across the board. Unfortunately, the deadlines proposed at that time, of eradication by 2000 
and certification by 2005, have joined the list of missed opportunities in the history of public health in India ${ }^{22}$.

What were the factors responsible for the missing of these targets in India, which appeared in 1995 to have broad-based political and scientific support locally? Most significantly, perhaps, the main tenet of eradication - the strengthening of ongoing routine immunisation programmes (RI) - was never followed. Instead, RI coverage appears to have been weakened following the introduction of the PPI strategy, which has been noted by the country's Planning Commission; this influential federal body has recorded these adverse trends in its Tenth Five Year Plan document, after drawing upon data gathered under the aegis of the National Family Health Survey $(\text { NFHS })^{23}$. The Table 1, based on NFHS data, shows that Andhra Pradesh, Delhi, Gujarat, Himachal Pradesh, Karnataka, Kerala, Maharashtra and Tamil Nadu states have all registered a decline in the proportion of fully immunised children (12-23 months) and also for OPV-based work, which require three doses of immunisation (for the sake of simplicity, we will refer to these as OPV 1-3).

This pessimism has been confirmed by other analysts. The District Level Household Survey
(DLHS), for instance, has reported a decline, nationally, in the proportion of fully immunised children; from $54 \%$ in $1998-99$ to $48 \%$ in $2002-04$ (large variations have, of course, also been reported in RI coverage across Indian states - from $97 \%$ in Kerala to $21 \%$ in Bihar $)^{24}$. Commentators have blamed the significance accorded to PPI for official and civilian "fatigue", which, it is claimed, has created vast pools of un-immunized children ${ }^{25}$.

Alternative arguments are also visible, of course. The improvements in RI coverage in the states of Bihar and Uttar Pradesh have been showcased by GPEI programme officers, who have been known to claim that these trends are representative of a major turnaround of public health conditions in these regions. However, the figures from these two states need to be scrutinised closely, which can be done, for instance, by using the NFHS data reproduced in the Table 2.

What is significantly different in these two states - in comparison to the rest of India - is the divergence between the coverage rates of OPV versus the Diphtheria-Pertussis-Tetanus (DPT) vaccines. As these sets of vaccines are administered simultaneously, one expects to see a close correlation between these two figures; yet, this is not the case in Bihar $(82.4 \%$ for OPV versus

Table 1. Comparisons between OPV and general immunisation in selected states in India.

\begin{tabular}{|c|c|c|c|c|}
\hline & & $\begin{array}{l}\text { National Family } \\
\text { Health Survey } 1\end{array}$ & $\begin{array}{l}\text { National Family } \\
\text { Health Survey } 2\end{array}$ & $\begin{array}{l}\text { National Family } \\
\text { Health Survey } 3\end{array}$ \\
\hline \multirow[t]{2}{*}{ India } & $\%$ fully immunised & 43.5 & 42.0 & 35.5 \\
\hline & $\%$ OPV1-3 coverage & 53.6 & 62.8 & 78.2 \\
\hline \multirow[t]{2}{*}{ Andhra Pradesh } & $\%$ fully immunised & 45.4 & 58.7 & 46.0 \\
\hline & $\%$ OPV1-3 coverage & 68.2 & 81.6 & 79.2 \\
\hline \multirow[t]{2}{*}{ Delhi } & $\%$ fully immunised & 57.8 & 69.8 & 63.2 \\
\hline & $\%$ OPV1-3 coverage & 75.6 & 81.0 & 79.1 \\
\hline \multirow[t]{2}{*}{ Gujarat } & $\%$ fully immunised & 50.0 & 53.0 & 45.0 \\
\hline & $\%$ OPV1-3 coverage & 63.6 & 68.6 & 65.3 \\
\hline \multirow[t]{2}{*}{ Himachal Pradesh } & $\%$ fully immunised & 63.5 & 83.4 & 74.2 \\
\hline & $\%$ OPV1-3 coverage & 78.4 & 89.6 & 88.6 \\
\hline \multirow{2}{*}{ Karnataka } & $\%$ fully immunised & 52.2 & 60.6 & 55.0 \\
\hline & $\%$ OPV1-3 coverage & 71.4 & 78.3 & 73.8 \\
\hline \multirow[t]{2}{*}{ Kerala } & $\%$ fully immunised & 77.4 & 79.0 & 75.3 \\
\hline & $\%$ OPV1-3 coverage & 74.2 & 88.1 & 83.1 \\
\hline \multirow[t]{2}{*}{ Maharashtra } & $\%$ fully immunised & 64.3 & 78.4 & 58.8 \\
\hline & $\%$ OPV1-3 coverage & 81.8 & 90.8 & 73.4 \\
\hline \multirow{2}{*}{ Tamil Nadu } & $\%$ fully immunised & 65.1 & 88.8 & 80.8 \\
\hline & $\%$ OPV1-3 coverage & 86.0 & 98.0 & 87.8 \\
\hline
\end{tabular}

Source: www.nfhs3.org; National Family Health Survey 3 Fact Sheets. Note: OPV 1-3 - Three waves of OPV-based immunisation work. 
Table 2. Comparisons between OPV, DPT and general immunisation in Bihar and Uttar Pradesh.

\begin{tabular}{llccc}
\hline & & $\begin{array}{c}\text { National Family } \\
\text { Health Survey }\end{array}$ & $\begin{array}{c}\text { National Family } \\
\text { Health Survey 2 }\end{array}$ & $\begin{array}{c}\text { National Family } \\
\text { Health Survey 3 }\end{array}$ \\
\hline Bihar & \% fully immunised & - & 11.6 & 32.8 \\
& \% OPV1-3 coverage & - & 42.2 & 82.4 \\
\multirow{4}{*}{ Uttar Pradesh } & \% DPT1-3 coverage & - & 24.9 & 46.1 \\
& \% fully immunised & - & 20.2 & 22.9 \\
& \% OPV1-3 coverage & - & 41.3 & 87.5 \\
& \% DPT1-3 coverage & - & 32.7 & 30
\end{tabular}

Source: www.nfhs3.org; National Family Health Survey 3 Fact Sheets.

Note: DPT - Diphtheria-Pertussis-Tetanus Vaccine; OPV - Oral Polio Vaccine.

46.1\% for DPT) and Uttar Pradesh $(87.5 \%$ for OPV versus $30 \%$ for DPT). When viewed in comparative perspective, these figures look even less impressive ${ }^{26}$.

Another important consideration in an eradication programme is the reliable monitoring of the vaccinal status of the target population and the reporting of disease. In India, the assessment of immunisation coverage amongst children has relied largely on the oral testimony provided by parents; recent evidence from Turkey has questioned this method ${ }^{27}$. Presentations based on these sources of information at the seventeenth meeting of the India Expert Advisory Group (IEAG), which was held in May 2007, indicated that there were 473 cases of wild polio virus (WPV). Of these, $85 \%$ had received more than three doses of OPV and nearly one-third received ten doses or more. By contrast, 99\% of 6749 non-polio cases of Acute Flaccid Paralysis (AFP) received more than three doses and 805 cases received more than ten doses $^{28}$.

It is worth noting that in Western Uttar Pradesh, over two-thirds of cases continue to occur below the age of 24 months; the median age of incidence is in the range of $12-18$ months $^{29}$. The official position is that more than $90 \%$ of the children under 5 received e" 10 doses in Uttar Pradesh. What is significant - and of some epidemiological concern - is that, according to parents' reports, about $10 \%$ of children below one year and about two-thirds of the children younger than two years reached the level of e"10 doses. This is significant in a situation where influential gatherings like the seventeenth IEAG have continued to note with concern that WPV persists as a disease of very young children; recommendations that the younger age groups be immunized, over a shorter period of time, thus continues to be widely urged ${ }^{30}$.
A recent study carried out in two endemic districts in Uttar Pradesh - Moradabad and J. P. Nagar - found district level programme managers and medical officers complaining of lack of flexibility in local level decision making. They reported that field workers were working under great pressure and that outbreaks of WPV had brought on the threat or imposition of penalties from the top, all of which was leading to demoralization and discontent amongst personnel operating in the localities ${ }^{31}$. These trends appear to exist elsewhere as well, particularly in Western Uttar Pradesh and some districts of Bihar; these regions have emerged as pockets of endemic polio. Disease endemicity in these "hotspots" has been variously attributed to biological determinants like the "peculiar environmental and socio-demographic milieu of Western UP (high population density, high birth rate, poor sanitation, etc.) coupled with poor SIA performance with consequent low coverage", as well as to programmatic and social determinants like the "falsification of data and fierce resistance by the minority community" 30 .

Investigations also reveal that outpatient services provided by primary healthcare centres (PHC) and work carried out by other public health programmes have been disrupted by polio-related activities. For this reason, "why only polio?" is a question frequently posed by junior officials and civilians ${ }^{32}$. Problems consequently caused for GPEI workers have led to wide-ranging initiatives of doubtful long-term viability, like cases where local level political and civilian leaders distributing cash in order to improve acceptance of the vaccine. More worryingly, there appear to have been cases where polio vaccination was carried out forcibly by health administrators, with support received from local police forces; apart from creating hostility within affected communities, it has caused nervousness about 
the aims of the GPEI within territories where the news of the use of compulsion has spread. This, perhaps, explains the continued existence of suspicion and resistance towards GPEI programmes in certain pockets, most notably amongst sections of different Muslim communities, as well as economically and socially disadvantaged Hindu communities like the Dalits. A recent decision to administer a single dose of OPV to all Haj pilgrims above sixteen years and infants below two years has not helped clarify matters in relation to the GPEI. In a situation where there is no evidence to suggest that adults act predominantly as carriers or that a single dose offers sufficient immunity, Muslim individuals affected by the policy - and their political and social representatives - have been wondering why the GPEI workers only target children. The many facets of "Muslim" resistance have been widely reported by the media over a period of time ${ }^{33}$.

It must be noted here that the nature of opposition to GPEI work is highly complex and cannot simply be explained by religious affiliation particularly to the Islamic faith - alone. Local development issues are increasingly becoming bargaining points been state representatives and community groups, and resistance to PPI is often visible in areas where civilian demands for roads, bridges or public food distribution systems have not been met. The local media - writing in Hindi and Urdu - has contributed to the dissemination of news and exaggerated reports of WPV and vaccinal side-effects, which have stoked uncontrolled rumours and parental nervousness about OPV. This is at least partially attributable to the GPEI management's inability to develop a consistent policy for engagement with the media; although Unicef's presentation at the seventeenth IEAG claimed that there has been a significant reduction in the hostility of local media, a lot remains to be achieved ${ }^{32}$. Interestingly, interviews conducted recently by Rajib Dasgupta amongst village headmen and PHC medical officers in the East Khasi and Ri Bhoi districts of Meghalaya state in North-Eastern India, indicates the presence of a similar complex interplay between rumours about GPEI work and resistance to OPV-based immunisation; worryingly, these trends appear to have fuelled partially by the Christian clergy and local media, which have raised numerous objections to components of the anti-polio campaign in that region ${ }^{34}$.

Several solutions have been put forth as the best means of tackling the complex challenges being faced by GPEI officials in the field, in India and elsewhere. A study prepared by Grassly et al..$^{35}$ claimed that the polio 2006 outbreak indicated "stark evidence of the need for high coverage with multiple doses of vaccine as early as possible in life in these areas" and suggested "sustained dialogue with local communities and strong political commitment" ${ }^{35}$. But, community dialogue and participation has been interpreted in relatively indifferent ways by GPEI's managers. Rather than working on a concerted basis with PHC workers of all grades, they have independently developed and deployed numerous "social mobilisation strategies"; in the high risk areas of Bihar and Uttar Pradesh, this has taken the shape of a communication platform and network called SMNet, which was created by Unicef in 2001. It is noteworthy that GPEI-sponsored "social mobilisation" work draws substantially on ideas that focus on the application of marketing principles to social services, wherein strategies are developed for the creation of demand for a specific product and its acceptance amongst targeted communities. These ideas can, in turn, be linked to the development of schemes of selective primary health care (SPHC), which emerged as a result of a consensus in some circles that the PHC approach advocated in Alma Ata was far too broad and unachievable. The architects of SPHC, therefore, recommended that political leaderships be presented with specific attainable goals such as disease eradication, which could then be developed alongside other healthcare measures in consultation with a large number of stakeholders $^{36,37}$.

In practice, however, the inflexible verticality of the GPEI has left relatively little space for community involvement in strategic planning and policy deployment. Although it cannot be denied that the social mobilization is a great improvement over the passive transmission of health education messages by the Indian federal and state authorities through mass media, the project is based largely on a top-down approach that does not adequately address the plethora of local social, political and economic conditions encountered across the country. The GPEI's biggest weakness lies therein, especially in relation to the localities of India. Commentators have, therefore, been urging that GPEI-related social mobilization programmes address the specificities of local health service systems and communities while advocating new policies. They have also pointed out that community dialogue be combined with existing social mobilization strategies. Indeed, analysts keep recommending the identification of key per- 
sons or groups at different levels of the civilian administration and the community; they also urge that differential needs of a community, based on age, gender, class, caste, religion and education be considered. All these reforms, when introduced, would, it has been argued, help increase vaccinal coverage and ensure greater levels of support for GPEI work. Interestingly, similar sentiments have also been echoed by the WHA in 2007 (held over 14-23 May), which urged all countries with endemic polio to establish mechanisms that would enhance political commitment and civilian participation in poliomyelitis eradication activities at all levels ${ }^{38}$. It is incumbent on the GPEI managers, in India and elsewhere, to respond positively to this call for operational openness; the future continuation of systematic polio immunisation appears to depend on it.

\section{Concluding comments}

Describing two global eradication programmes, as they have unfolded in complex forms in India, this article seeks to highlight issues that we consider worthy of consideration by policy designers and managers involved in work carried out in the Indian sub-continent. Comparisons are made in the hope that the smallpox story can provide useful leads to the managers of the polio campaign, as it struggles to cope with fresh disease outbreaks, social opposition to reporting and vaccination, and not least operational disunities in the field. Although the biological nature of the diseases targeted by the two programmes are quite distinct, this article has tried to show that there is much more else to consider in the designing and the implementation of a global eradication effort. Lessons provided by the anti-smallpox campaign about the best ways to counter social, political, economic and technological challenges can be invaluable to GPEI managers and workers currently active in the sub-continent. Importantly, these messages are pertinent for officials located at all levels of national and local government, WHO and Unicef administration, and, not least, agencies providing funding for mass immunisation campaigns in the remaining polio endemic countries.

There has been a tendency amongst senior GPEI officials to formulate relatively inflexible prescriptions from a distance and efforts to impose these on local health workers by decree. These trends are attended by a general unwillingness to organise the systematic collection of information from within local communities, to use the resultant insights to adapt campaigns to local conditions and, indeed, to develop meaningful schemes of community partnership, where members of the target population are employed to work on polio reporting and vaccination. The experience of smallpox eradication in India - and in particular in Uttar Pradesh and Bihar - shows that such operational inflexibility can lead to a situation where polio remains endemic in the subcontinent; a worrying prospect for the goal of global polio eradication.

There is another global disease eradication programme whose history offers worrying insights into the long-term damage wreaked by the failure of a well-funded campaign - the unsuccessful effort to rid the world of malaria. Consistently dogged by technical difficulties after the problems faced with the use of DDT, this programme was also hamstrung by deep-seated administrative problems; these resulted mainly from the inflexible attitudes of a relatively small team of people in Geneva and New York, who appeared to believe that they could ensure the development of a unitary strategy that could then be implemented worldwide. The plan proved disastrous, as federal and local governments within sovereign nations reacted badly to the dictates from distant locations, and frequently refused to co-operate with WHO teams at crucial junctures. The disintegration of the malaria eradication programme resulted and hampered, for many years afterwards, efforts to resuscitate smaller regional malaria control programmes and the mobilisation of broad-based support for the global smallpox eradication programme. Well informed commentators had, of course, warned us about the pitfalls of ignoring the lessons provided by the doomed malaria programme and the successful smallpox campaign some years ago ${ }^{39}$. Unfortunately, such warnings appear to have been ignored by most of those in charge of running the GPEI, as we now know, to the great detriment of the programme.

One can only hope that the global polio eradication programme does not fail, even though some well-informed commentators have raised serious doubts about the possibility of success. To make polio eradication likelier, it is clear that the great challenges facing the national chapters of the GPEI, in India and elsewhere, will have to be tackled with greater sensitivity and care ${ }^{40}$. If the lessons of the final phases of the smallpox programme are taken on board, there can be little doubt that careful preparation, operational flexibility and the deployment of international 
staff willing to spend long stints in the field and work in close association with health personnel is of great importance. In India specifically, broadbased from the political and administrative establishment, in New Delhi and state governments and legislatures, would help increase the morale of local vaccinators and supervisors. Such a situation would also make it easier for international workers to engage in GPEI work in the troubled districts and sub-divisions; importantly, so would greater levels of unanimity within the various WHO and Unicef offices. Such reforms, when introduced, would have long term benefits, even if polio was never eradicated, and the long term goal was converted to one of eliminating and controlling the spread of the disease. Indeed, operational clarity and flexibility in the field would help in the development and running of a regularised polio vaccination programme, as well as a host of immunisation projects, which would help the long term survival of a meaningful global and national EPI projects; this, in turn, would help reduce childhood mortality and also increase the quality of children's lives worldwide ${ }^{20}$.

\section{Collaborations}

S Bhattacharya conceptualized this paper, after which R Dasgupta and he spent equal effort in putting the piece together.

\section{Acknowledgements}

We would like to acknowledge the support of the Wellcome Trust, UK, which funded the bulk of the research underpinning the preparation of this article.

\section{References}

1. Fenner F, Henderson DA, Arita I, Jezek Z, Ladnyi ID. Smallpox and its eradication. Geneva: WHO; 1988. p. 369-371.

2. Memorandum from Regional Director, WHO SEARO, New Delhi, to Director, Division of Communicable Diseases, WHO HQ, Geneva, $18^{\text {th }}$ August 1961, File SPX-1, Box 545, Smallpox Eradication Archives, WHO HQ (hereafter SEA/WHO).

3. Letter from the British High Commissioner, India, to Commonwealth Relations Office, Government of Britain, $5^{\text {th }}$ November 1962, MH 55/2520, National Archives of Britain, Kew, Surrey, and letter from D.A. Henderson, Chief, Smallpox Eradication Unit, WHO HQ, to Regional Director, WHO SEARO, New Delhi, $4^{\text {th }}$ August 1967, File 416, Box 193, SEA/WHO.

4. Proceedings of the third meeting of the newly constituted Advisory Committee of the National Smallpox Vaccination Eradication Programme held (in New Delhi); 1965 November $16^{\text {th }}$; New Delhi. File 416, Box 193, SEA/WHO.

5. Memorandum from Dr. F.G.L. Gremlinka and Dr. J. Keka, WHO SEARO, New Delhi, to WHO HQ, Geneva, $7^{\text {th }}$ February 1967, File 416, Box 193, SEA/WHO, and letter from D.A. Henderson, Chief, Smallpox Eradication Unit, WHO HQ, Geneva, to Director General of Health Services, Government of India, New Delhi, $21^{\text {st }}$ February 1967, File 416, Box 193 SEA/WHO. 
6. Telegram from Assistant Director General, WHO HQ, Geneva, to Regional Director, WHO SEARO, New Delhi, $4^{\text {th }}$ April 1967, File 416, Box 193, SEA/ WHO. Also see, letter from D.A. Henderson, Chief, Smallpox Eradication Unit, WHO HQ, Geneva, to Dr. Ernest Tierkel, USAID, American Embassy, New Delhi, $12^{\text {th }}$ April 1967, and confidential letter from Dr. K. Raska, Director, Division of Communicable Diseases, WHO HQ, Geneva, to Assistant Director General, WHO HQ, $5^{\text {th }}$ April 1967, in File 416, Box 193, SEA/WHO.

7. Memorandum from Regional Director, WHO SEARO, New Delhi, to D.A. Henderson, Chief, Smallpox Eradication Unit, WHO HQ, Geneva, $5^{\text {th }}$ January 1968, File 416, Box 193, SEA/WHO.

8. Interview with Dr. Mahendra Dutta, conducted by Sanjoy Bhattacharya. India: New Delhi; May $7^{\text {th }}$, 1999.

9. Letter from Dr. Nicole Grasset, Regional Advisor, Smallpox Eradication Unit, WHO SEARO, New Delhi, to D.A. Henderson, Chief, Smallpox Eradication Unit, WHO HQ, Geneva, $15^{\text {th }}$ September 1972, and personal letter from D. A. Henderson, Chief, Smallpox Eradication Unit, WHO HQ, Geneva, to Dr. Nicole Grasset, Regional Advisor, Smallpox Eradication Unit, WHO SEARO, New Delhi, $26^{\text {th }}$ September 1972, in File 830, Box 194, SEA/WHO.

10. Personal letter from Larry Brilliant, WHO SEARO, New Delhi, to D.A. Henderson, Chief, Smallpox Eradication Unit, WHO HQ, Geneva, $20^{\text {th }}$ July 1973 , and personal letter from Dr. Z. Jezek, Consultant, WHO SEARO, New Delhi, to D.A. Henderson, Chief, Smallpox Eradication Unit, WHO HQ, Geneva, $18^{\text {th }}$ May 1973, in File 830, Box 194, SEA/WHO. Also see, "India Smallpox Eradication Programme - Status and Strategy, 27th June 1974", c.1974, File 388, Box 194, SEA/WHO, and letter from D.A. Henderson, Chief, Smallpox Eradication Unit, WHO HQ, Geneva, to R. Lickfett, Senior Programme Officer, Swedish International Development Agency, Stockholm, $1^{\text {st }}$ July 1974, File 948, Box 17, SEA/WHO.

11. Letter from Lawrence Brilliant, WHO SEARO, New Delhi, to J.R.D. Tata, Bombay, $25^{\text {th }}$ June 1974, File 388, Box 194, SEA/WHO.

12. Bhattacharya S. Expunging variola: the control and eradication of smallpox in India, 1947-77 [?]. Delhi and London: Orient Longman and Sangam Books: 2006. p. 199-202.

13. Letter from Grasset N. Regional Advisor, Smallpox Eradication Unit, WHO SEARO, New Delhi, to D.A. Henderson, Chief, Smallpox Eradication Unit, WHO HQ, Geneva, $30^{\text {th }}$ June 1975, File 831, Box 195, SEA/ WHO.

14. Letter from D.A. Henderson, Chief, Smallpox Eradication Unit, WHO HQ, Geneva, to R. Lickfett, Senior Programme Officer, Swedish International Development Agency, Stockholm, $1^{\text {st }}$ July 1974, File 948, Box 17, SEA/WHO.

15. Public lecture presented by Alan Schnur, WHO HQ, Geneva, at the Wellcome Trust Centre for the History of Medicine at UCL, UK, on the $5^{\text {th }}$ of December 2007; a recording of this speech can be accessed at the Wellcome library and archives, London, UK.
16. John TJ. Can we eradicate poliomyelitis? In: Sachdev HPS, Choudhury P, editors. Frontiers in paediatrics. New Delhi: Jaypee Brothers Medical Publishers; 1996. p. 76-90.

17. World Health Organization (WHO). Forty First World Health Assembly, Geneva 2-13 May, 1988, WHA 41.28 Global Eradication of Poliomyelitis by the Year 2000. (cited 2007 December 20); available from: http:// www.who.int/csr/ihr/polioresolution4128en.pdf

18. Dowdle WR. The principles of disease elimination and eradication. Bulletin of the World Health Organisation 1998; 76(2):22-25.

19. World Health Organization (WHO). Report of the Second Meeting of the Global Commission for the Certification of the Eradication of Poliomyelitis. (cited 1998 May 1); available from: http://www.who.int

20. Annual Pumphandle Lecture for 2007, titled "Polio eradication: a reconsideration of strategy" by D.A. Henderson. An audio recording of the lecture and slides containing data presented at the event can be accessed at the John Snow Society's website available from: http://www.johnsnowsociety.org/lectures/ lecture2007.html

21. Sathyamala C, Mittal O, Dasgupta R, Priya R. Polio eradication initiative in India. International Journal of Health Services 2005; 35(2):361-383.

22. Puliyel JM, Gupta MA, Mathew JL (editorial). Polio eradication and the future for other programmes: situation analysis for strategic planning in India. Indian J Med Rese 2007; 125(1):1-4.

23. Planning Commission. Tenth Five-Year Plan 20022007. Volume II, Sectoral Policies and Programmes, Family Welfare. New Delhi: Government of India; undated. p. 194-196.

24. CDC. Progress Towards Polio Eradication, India 2002. Morbidity and Mortality Weekly Report 2003; 52:172-175.

25. Thacker N, Shendurnikar N. Current status of polio eradication and future prospects. Indian Journal of Pediatrics 2004; 71:241-245.

26. International Institute of Population Sciences. NFHS3 Fact Sheets. (cited 2007 October 18); available from: www.nfhs3.org

27. Vancelik S, Guraksin A, Ayyildiz A, Beyhun NE. Seroepidemiology of poliovirus antibody among the children in Eastern Turkey. Indian J Med Rese 2007; 126(December):528-533.

28. Thacker N. Polio eradication: window of opportunity. Indian Paediatrics 2007; 44:81-82.

29. John TJ. Establish herd effect to interrupt wild poliovirus transmission. Indian J Med Rese 2006; 126:1-4.

30. National Polio Surveillance Project. Conclusions and recommendations. The Seventeenth Meeting of the India Expert Advisory Group for Polio Eradication 20-29 May 2007; Delhi, India. (cited 2007 September 4]; available from: www.npspindia.org

31. Dasgupta R, Chaturvedi S, Adhish V, Ganguly KK, Rai S, Sushant L, Lakshman M, Arora NK. Social determinants of the polio eradication program - 20062007. New Delhi: INCLEN; 2007.

32. Unicef. India Communication Update no. 6, June 2007. [cited 2007 November 2]; available from: http:/ /www.unicef.org 
33. Government of Uttar Pradesh. (cited 2006 October 15); available from: http://www.upgov.nic.in/news

34. Interviews with medical officers and village headmen of Umsing Block, Ri Bhoi District and Mawryngkneng Block, East Khasi District and paediatricians at North Eastern Indira Gandhi Regional Institute of Health and Medical Sciences, Shillong. Meghalaya, India, October 13-16, 2007, conducted by Rajub Dasgupta.

35. Grassly NC, Wenger J, Durrani S, Bahl S, Deshpande JM, Sutter RW, Heymann DL, Aylward RB. Protective efficacy of a monovalent oral type 1 poliovirus vaccine: a case control study. Lancet 2007; 369(9575):1356-1362.

36. Chen L. Ten years after Alma Ata: balancing different primary health care strategies. State of the art lectures, XIII International Congress for Tropical Medicine and Malaria. Supplement to Tropical and Geographic Medicine 1988; 40(S):22-29.

37. Henderson RH. Keynote address, Proceedings of the Conference on Global Disease Elimination and Eradication as Public Health Strategies. Bulletin of the World Health Organisation 1998; 76(2):14-16.

38. World Health Organization (WHO). Address to the Sixtieth World Health Assembly, Dr. Margaret Chan, Director General of the World Health Organization. (cited 2007 October 28); available from: http:/ /www.who.int/mediacentre/events/2007/wha60/en/ index.html

39. Henderson DA. The principles of disease elimination and eradication. Bulletin of the World Health Organisation 1998; 76(2):17-21.

40. Arora NK, Dasgupta R, Sushant L. The polio eradication initiative in India: need for evidence based actions. Indian J Med Rese 2007; 126(6):500-501.

Artigo apresentado em 19/07/2010

Aprovado em 5/11/2010

Versão final apresentada em 29/11/2010 